\title{
OUTCOME BASED EDUCATION IN ENGINEERING: THE NEED FOR QUALITY AND TRANSFORMATIVE ASSESSMENT
}

\author{
ONYEKA, JOY NKERIUKA (Ph.D) \\ Department of Educational Psychology/ Guidance and Counselling, \\ Alvan Ikoku Federal College of Education Owerri \\ joynonyeka@yahoo.com \\ ONYEKA, JULIUS OKEZUO \\ Professor of Structural Engineering, \\ Imo State University, Owerri \\ Juliusonyeka@Yahoo.Com
}

\begin{abstract}
The paper studied the assessment practices in Engineering faculties in Nigerian Universities under the outcome based education system. The aim is to determine the quality and transformative nature of the assessment. Four research questions were used for the study. Ninety five (95) engineering lecturers from the Imo State University and the Federal University of Technology all in Owerri, were used for the study. Conscious effort was made to ensure that all disciplines available in the two institutions were represented. A questionnaire with a rating scale was used to obtain the data. The data were analysed using mean rating. It was found that the lecturers are aware of the demand of assessment under the OBE system and in fact, practice some of the strategies. However, the facilities are in short supply, especially electricity. The paper recommends among other things that proprietors of universities and other institutions of higher learning should endeavour to provide needed facilities.
\end{abstract}

Key words: Assessment, Engineering, Education, Outcome, Quality, Transformative, Facilities. 


\section{Introduction}

Engineering is basically aimed at the utilization of knowledge of applied science to solve the problems of society. The aim of engineering education, therefore, is to produce elite human beings that are versatile and functional in their actions to the extent that they are able to deploy the acquired resourceful and creative skills in the design and development of new product as well as in the installation and maintenance of complex engineering systems for optimal performance. Onyeka, Onuekwusi and Dara (2018:157) describe engineering as "an applied science that deals with the design and construction of machines and general facilities with economy". They observed that engineering is practically oriented and, therefore, the products of engineering education should be practically oriented individuals who can innovate, invent and develop machines and general facilities at reduced cost. It goes without argument that engineering touches all aspects of human endeavor. Whatever the area of engineering, be it agricultural, civil, and electrical, electronics, mechanical, chemical, computer, food, gas, materials and metallurgical, structural etc, it has a direct or indirect link with human existence.

In its benchmark minimum academic standard (BMAS) document, the National Universities Commission (2018) maintains that engineering graduates should be able to "exercise original thought, have good professional judgment and be able to take responsibility for the execution of important tasks". According to the NUC, the graduates are also expected to be able to improve on indigenous technology for deployment to the solution of local problems". Engineering education can, therefore, be described as the tripod on which the survival of both human beings and infrastructural facilities rests. The training programme for full-time students runs for five years for a Bachelor of Engineering degree (B.Eng), eighteen months for a Master of Engineering programme (M.Eng) and thirty-six months for a Doctor of Philosophy programme (Ph.D).

In its desire to internationalize Nigeria's engineering education cum degrees and ensure mobility of labour, the Council for the Regulation of Engineering in Nigeria (COREN) is seeking affiliation to notable world bodies including the International Engineering Alliance (IEA) and the Washington accord. A successful affiliation would enable engineering graduates from COREN accredited engineering programmes and universities to gain international recognition. Thus, an Engineering graduate of Imo State University, for instance, can walk into any office in the United States, United Kingdom and similar other countries to present his/her degree for employment without first being subjected to another training. A basic requirement of these international alliances is that the engineering curriculum must embrace outcome based education. To comply with this requirement, COREN in 2017 revised its Benchmark Minimum Academic Standards (BMAS) and accreditation scoring criteria. Universities in Nigeria have been directed by COREN to adopt the new curriculum or lose their accreditation status. The question now is, what is outcome based education and what assessment strategies can enhance it?

Unlike the traditional system which is knowledge based, the outcome based education (OBE) curriculum emphasizes what the engineering graduate is able to do, as against what he/she knows. It encourages and promotes "hands on tools". There is an emphasis on psychomotor domain of learning where learners are expected to make use of any part of their body to achieve a task. While insisting on a worthwhile theoretical background, the OBE also insists on practical and project based learning. Under the OBE, three concepts are of paramount importance. These are; 
1. The Programme Education Objectives (PEO)

2. The Programme Outcome (PO)

3. The Course Learning Outcomes (LO).

According to COREN (2017), programme education objectives are attributes expected of graduates of the engineering programme between 3-5 years after graduation. In developing this, all stakeholders make input. The programme outcome is what the graduate of a programme is able to do immediately on graduation and the learning outcome is the expectation at the end of each semester course. By the outcome based education method, COREN insists that teaching methods should "include lectures, laboratory practicals, tutorials, seminars, workshop practices, industrial work experience, assignments, case studies, excursions, power point presentations and documentary films".

There is no doubt that the outcome based education system is what is needed to salvage the Nigerian nation. The programme, if religiously implemented, will put an end to the craze for paper qualification among young engineers. Among other things, the system lets the teacher try always to answer the following questions: Are my students learning? What are they learning? What affects their learning and how much have they learnt? This is unlike the old educational approach where learners are largely passive, examination driven and rote learners. As desirable as the OBE is, it requires special skills in developing assessment methods for the students if the lofty ideals are to be fully realized.

Assessment methods are the strategies, techniques, tools and instruments for collecting information to determine the extent to which students or learners demonstrate desired learning outcomes. With a changed method of delivery of the lesson and a changed expectation of the outcome, there must also be an appropriate choice of method of assessment. Assessment must not be confused with testing. Bloom's taxonomy must be effectively considered. As has been said, the OBE is based on the psychomotor level. This, therefore, implies that many strategies should be considered in assessing outcome based learning. The assessor must not be myopic but rather should embrace multi-methods and techniques to ascertain whether the desired goal is being achieved. If the right exposure is given, the right assessment should also be put in place in other to achieve the needed transformation. To achieve the aims of OBE, the teacher who eventually is the assessor, should realize that each learner is different from the other in completing tasks. While some are fast, others are slow. It is, therefore, important to encourage active participation. Also, assessment should be made a continuous thing instead of a one shot affair.

Nkwocha (2014), citing Encyclopedia of Education (1976), noted that assessment is a multitrait, multi-methods and multi-source process. In other words, a wide variety of methods and instruments are used to obtain the needed information concerning a learner. However, the learner's assessment must be such that will enhance critical thinking, reasoning, reflective actions, synthesizing, analyzing and one that is justifiable. To corroborate this, Onyeka, Onuekwusi and Dara (2018) assert that quality assessment is the bedrock of any meaningful evaluation and to be able to make a comprehensive decision regarding academic achievements, it is important to ensure that the assessment strategies employed have quality.

There is also the need for the assessment strategy to be transformative. Notably, Google.com (2017) describes engineers as the experts who know what makes a product or process work. As such, they should have the ability to influence the outcome of any product. Any assessment method that does not bring out this inert ability in the young engineer is 
counterproductive. It becomes more compelling when it is realized that the engineer is unlikely to buy into a transformation unless he/she believes in its merits. Being a transformative creature, the assessment of the engineer must also be transformative in order to achieve sustainability, especially in an emerging economy such as Nigeria's.

This paper, therefore, sets out to study the quality and transformative strategies that will enhance effective and meaningful assessment of the outcome based learner in engineering.

\section{Statement of the Problem}

The Outcome Based Education system (OBE) lays emphasis on what the graduate can do as opposed to the old system which emphasizes what the graduate knows. This demands a marked shift from the old ways of doing things. One of those ways of doing things which needs change is the way and manner of assessing the students. The assessment strategy must be of quality and must also be transformative. The problem then arises are the necessary conditions available for quality and transformative assessment of engineering students under the OBE system?

\section{Purpose of the Study}

The paper investigated the need for quality and transformative assessment under the Outcome Based Education system in engineering.

The specific objectives are:

1. To ascertain the extent to which engineering lecturers practice OBE assessment strategies.

2. To determine the extent to which engineering students are exposed to the OBE assessment modes.

3. To ascertain the availability of necessary facilities that aid OBE assessment.

4. To determine the level of assessment of students' actual use of available equipment during practicals.

\section{Research Questions}

The following questions were used as a guide during the study

1. To what extent do engineering lecturers practice OBE assessment strategies?

2. What is the extent of exposure of engineering students to OBE assessment modes?

3. How available are facilities that aid OBE assessment?

4. To what extent do engineering lecturers assess students' knowledge of use of laboratory equipment?

\section{Method}

A descriptive survey design was employed in this study since data was based on the existing situations. Engineering lecturers were used for the study because they are the ones that expose engineering students to instructions, assess them as well make judgments with regards to their academic achievement. They are in a better position to respond to the instruments of the study and are, therefore, the best suited to be used for the study. 
The sample was made up of 95 engineering lecturers from Imo State University and the Federal University of Technology Owerri. They were drawn using a stratified simple random sampling technique to ensure that lecturers from all disciplines of engineering available in the two universities were given equal opportunity to be drawn for the study.

A questionnaire was used to obtain data for the research questions. The questionnaire has a rating scale based on the continuum of Strongly Agree (SA)/Very high extent (VHE); Agree (A)/High extents(HE); Disagree(D)/Low extent (LE); and Strongly Disagree (SD)/Very low extent (VLE). The weights attached to the response options are 4, 3, 2 and 1 point respectively. The weights are reversed for negatively keyed items.

The instrument was subjected to both face and content validity by three engineering lecturers and three experts in educational assessment. Their observations and corrections were effected before the production of the final draft. The instruments were further subjected to reliability measures and a reliability coefficient of 0.79 was obtained, using the split half measure. This result confirmed that the instrument was reliable and could be used to collect needed data for the study. Mean rating was used to analyze the data collected for the research questions. A criterion mean of 2.50 was set for the acceptance or otherwise of both the item means (X) and the grand means.

\section{Results}

The results of the analyses of the responses from the questionnaires are presented in Tables 1 to 4 .

Table 1: Extent of Practice of OBE Assessment Strategies by Engineering Lecturers.

\begin{tabular}{|c|c|c|c|c|c|c|c|}
\hline $\mathbf{S} / \mathbf{N}$ & Items/Statements & VHE & HE & $\mathbf{L E}$ & VLE & $\mathbf{X}$ & Remark \\
\hline 1. & $\begin{array}{l}\text { Students are assessed regularly in every course or } \\
\text { programme within the semester }\end{array}$ & $\begin{array}{l}48 \\
192\end{array}$ & $\begin{array}{l}32 \\
96\end{array}$ & $\begin{array}{l}10 \\
20\end{array}$ & $\begin{array}{l}5 \\
5\end{array}$ & 3.29 & $\begin{array}{l}\text { Very High } \\
\text { Extent }\end{array}$ \\
\hline 2. & $\begin{array}{l}\text { The student's grade at the end of the semester } \\
\text { course is a cumulative of routine assessments }\end{array}$ & $\begin{array}{l}30 \\
120\end{array}$ & $\begin{array}{l}25 \\
22\end{array}$ & $\begin{array}{l}30 \\
28\end{array}$ & $\begin{array}{l}15 \\
15\end{array}$ & 2.71 & High Extent \\
\hline 3. & $\begin{array}{l}\text { The performance of students helps the lecturer to } \\
\text { improve on his performance }\end{array}$ & $\begin{array}{l}25 \\
100\end{array}$ & $\begin{array}{l}25 \\
75\end{array}$ & $\begin{array}{l}30 \\
60\end{array}$ & $\begin{array}{l}15 \\
15\end{array}$ & 1.58 & $\begin{array}{l}\text { Very Low } \\
\text { Extent }\end{array}$ \\
\hline 4. & $\begin{array}{l}\text { Set goals and processes are considered in } \\
\text { assessing the students. }\end{array}$ & $\begin{array}{l}23 \\
92\end{array}$ & $\begin{array}{l}24 \\
72\end{array}$ & $\begin{array}{l}31 \\
62\end{array}$ & $\begin{array}{l}17 \\
17\end{array}$ & 2.56 & High Extent \\
\hline 5. & $\begin{array}{l}\text { Diverse instruments are used to assess students } \\
\text { on each occasion. } \\
\text { Grand Mean }\end{array}$ & $\begin{array}{l}20 \\
80\end{array}$ & $\begin{array}{l}15 \\
45\end{array}$ & $\begin{array}{l}35 \\
70\end{array}$ & $\begin{array}{l}25 \\
25\end{array}$ & $\begin{array}{l}2.32 \\
\mathbf{2 . 6 9}\end{array}$ & Low Extent \\
\hline
\end{tabular}


Table 1 reveals that regular assessment of engineering students in every semester course or programme attracts a low extent with a mean value of 2.32. Basing the final grade in the course on the totality of the routine assessments attracts a value of 2.71. Lecturers' use of the result of assessment to improve on their own performance is to a very low extent with a mean value of 1.58. Considering the set goals and processes while assessing the students is to a high extent with 2.56 and the use of diverse instruments to assess the students on each occasion has 2.32, which is to a low extent. The grand mean in this case is 2.69.

Table 2: Extent of Exposure of Engineering Students to OBE assessment modes.

\begin{tabular}{|c|c|c|c|c|c|c|c|}
\hline $\mathbf{S} / \mathbf{N}$ & Items/Statements & VHE & HE & $\mathbf{L E}$ & VLE & $\overline{\mathbf{X}}$ & Remark \\
\hline 1. & $\begin{array}{l}\text { Students are engaged in projects at every level of } \\
\text { the programme }\end{array}$ & $\begin{array}{l}32 \\
128\end{array}$ & $\begin{array}{l}43 \\
129\end{array}$ & $\begin{array}{l}10 \\
20\end{array}$ & $\begin{array}{l}10 \\
10\end{array}$ & 3.02 & $\begin{array}{l}\text { Very High } \\
\text { Extent }\end{array}$ \\
\hline 2. & $\begin{array}{l}\text { Students are engaged in both individual and } \\
\text { group assignments }\end{array}$ & $\begin{array}{l}47 \\
188\end{array}$ & $\begin{array}{l}30 \\
90\end{array}$ & $\begin{array}{l}4 \\
8\end{array}$ & $\begin{array}{l}14 \\
14\end{array}$ & 3.16 & $\begin{array}{l}\text { Very High } \\
\text { Extent }\end{array}$ \\
\hline 3. & $\begin{array}{l}\text { Laboratory practices are considered in students' } \\
\text { assessment. }\end{array}$ & $\begin{array}{l}25 \\
100\end{array}$ & $\begin{array}{l}20 \\
60\end{array}$ & $\begin{array}{l}35 \\
70\end{array}$ & $\begin{array}{l}15 \\
15\end{array}$ & 2.58 & High Extent \\
\hline 4. & $\begin{array}{l}\text { Workshop practicals are used in assessment of } \\
\text { students. }\end{array}$ & $\begin{array}{l}43 \\
172\end{array}$ & $\begin{array}{l}37 \\
111\end{array}$ & $\begin{array}{l}04 \\
08\end{array}$ & $\begin{array}{l}11 \\
11\end{array}$ & 2.13 & Low Extent \\
\hline 5. & $\begin{array}{l}\text { SIWES performance is part of assessment for } \\
\text { engineering students }\end{array}$ & $\begin{array}{l}51 \\
204\end{array}$ & $\begin{array}{l}37 \\
111\end{array}$ & $\begin{array}{l}07 \\
14\end{array}$ & $\begin{array}{l}0 \\
0\end{array}$ & 3.46 & $\begin{array}{l}\text { Very High } \\
\text { Extent }\end{array}$ \\
\hline 6. & Fieldwork/site visits by students are assessed. & $\begin{array}{l}37 \\
148\end{array}$ & $\begin{array}{l}35 \\
105\end{array}$ & $\begin{array}{l}15 \\
30\end{array}$ & $\begin{array}{l}08 \\
08\end{array}$ & 3.06 & $\begin{array}{l}\text { Very High } \\
\text { Extent }\end{array}$ \\
\hline 7. & Seminar presentations by students are assessed. & $\begin{array}{l}29 \\
116\end{array}$ & $\begin{array}{l}36 \\
108\end{array}$ & $\begin{array}{l}20 \\
40\end{array}$ & $\begin{array}{l}16 \\
10\end{array}$ & 2.88 & High Extent \\
\hline 8. & $\begin{array}{l}\text { Group works by the students are assessed. } \\
\text { Grand Mean }\end{array}$ & $\begin{array}{l}25 \\
100\end{array}$ & $\begin{array}{l}20 \\
60\end{array}$ & $\begin{array}{l}25 \\
50\end{array}$ & $\begin{array}{l}25 \\
25\end{array}$ & $\begin{array}{l}2.47 \\
\mathbf{2 . 8 5}\end{array}$ & Low Extent \\
\hline
\end{tabular}

Data in table 2 show that engineering students are exposed to OBE assessment tools with a grand mean of 2.85. The eight statements used to collect data for the analysis attracted item means of $3.02,3.16,2.58,2.13,3.46,3.06,2.88$ and 2.47 respectively. 
Table 3: Availability of Facilities that aid outcome Based Assessment.

\begin{tabular}{llllllll}
\hline S/N & Items/Statements & SA & A & D & SD & $\bar{X}$ & Remark
\end{tabular}

1. Classroom space are adequate

2. Vehicles for field trips are available

3. Functional workshop equipment are available

4. Workshop space are adequate

5. Functional Laboratory equipment are available

6. Laboratory space are adequate

7. Internet/e-learning facilities are available

8. Auto-cad studios are available

9. Simulation studios are available

10. There is regular electricity supply

$\begin{array}{llll}21 & 20 & 13 & 41 \\ 54 & 60 & 26 & 41\end{array}$

\subsection{Disagree}

$\begin{array}{llll}17 & 21 & 09 & 47\end{array}$

$\begin{array}{llll}68 & 63 & 18 & 47\end{array}$

1.97 Strongly

Disagree

$\begin{array}{llll}09 & 17 & 50 & 19\end{array}$

$\begin{array}{llll}36 & 51 & 100 & 19\end{array}$

2.17 Disagree

$\begin{array}{llll}18 & 20 & 20 & 37\end{array}$

$\begin{array}{llllll}72 & 60 & 40 & 37 & 2.20 & \text { Disagree }\end{array}$

$\begin{array}{llll}15 & 20 & 45 & 15\end{array}$

$\begin{array}{llll}60 & 60 & 90 & 15\end{array}$

$\begin{array}{llll}24 & 20 & 15 & 35\end{array}$

$\begin{array}{llll}96 & 60 & 30 & 35\end{array}$

$\begin{array}{llll}20 & 22 & 10 & 43\end{array}$

$\begin{array}{llll}80 & 26 & 20 & 43\end{array}$

$\begin{array}{llll}21 & 29 & 25 & 20\end{array}$

$\begin{array}{llll}84 & 87 & 50 & 20\end{array}$

$\begin{array}{llll}14 & 22 & 13 & 46\end{array}$

$\begin{array}{llll}56 & 66 & 26 & 46\end{array}$

$10 \quad 15 \quad 15 \quad 53$

$\begin{array}{llll}40 & 45 & 30 & 53\end{array}$

2.37 Disagree

2.33 Disagree

2.20 Disagree

2.54 Agree

2.04 Disagree

1.79 Strongly Disagree

\section{Grand Mean}

Table 3 shows that the grand mean for research question 3 is 2.18. The facilities attracted means below 2.50 except Auto-cad studios with a mean of 2.54. Adequacy of classroom space has 2.22, availability of vehicles for field trips has 1.97 , availability of workshop equipment has 2.17 and adequacy of workshop space is 2.20. Availability of simulation studios has 2.04 while regular electricity supply has 1.79 . 
Table 4: Assessment of students' actual use of available equipment during practicals.

\begin{tabular}{|c|c|c|c|c|c|c|c|}
\hline $\mathbf{S} / \mathbf{N}$ & Items/Statements & $\mathbf{S A}$ & $\mathbf{A}$ & $\mathbf{D}$ & SD & $\overline{\overline{\mathbf{X}}}$ & Remark \\
\hline \multirow[t]{2}{*}{1.} & Students are taken to the equipment to identify & 18 & 20 & 15 & 42 & & \\
\hline & the parts. & 72 & 60 & 30 & 42 & 2.14 & Disagree \\
\hline \multirow[t]{2}{*}{2.} & Students are asked to explain the functions of the & 25 & 18 & 10 & 42 & & \\
\hline & parts. & 100 & 54 & 20 & 42 & 2.27 & Disagree \\
\hline \multirow[t]{2}{*}{3.} & Students are asked to outline principles guiding & 14 & 27 & 13 & 46 & & \\
\hline & operations of the equipment. & 56 & 66 & 26 & 46 & 2.04 & Disagree \\
\hline \multirow[t]{2}{*}{4.} & Students are asked to give the necessary & 09 & 17 & 50 & 19 & & Disagree \\
\hline & precautions while in use. & 36 & 51 & 100 & 19 & 2.17 & \\
\hline \multirow[t]{2}{*}{5.} & In the laboratories, students are asked to explain & 20 & 25 & 22 & 28 & & \\
\hline & maintenance of the equipment. & 80 & 75 & 44 & 28 & 2.39 & Disagree \\
\hline \multirow[t]{3}{*}{6.} & Students are required to demonstrate hands on & 31 & 16 & 12 & 36 & & \\
\hline & tools for production. & 124 & 48 & 24 & 36 & 2.44 & Disagree \\
\hline & Grand Mean & & & & & 2.24 & \\
\hline
\end{tabular}

Table 4 shows that all the items used to find out if students are actually assessed on the use of available equipment during practicals attracted low means below 2.50 as follows: identifying equipment parts 2.14, explaining the functions of parts 2.27, outlining principles guiding their operations 2.04, giving necessary precautions 2.17, explaining maintenance of equipment 2.39, demonstration of hands on tools for production 2.44. The grand mean is 2.24.

\section{Discussion}

Research question one attracted an average mean of 2.69. This shows that engineering lecturers practice necessary assessment strategies needed for a successful implementation of the outcome based education system. These practices include routine assessment of the students without waiting for the end of semester examination, putting more efforts and taking more seriously the framing of the questions, recognizing goals and processes, as well as approaching assessment from diverse directions and with different measures. This positive result of this research question shows that the future of the outcome based education system could be very bright because if the lecturers know the demand of OBE assessment, they will strive to do the needful. When the necessary things are done and the necessary steps are taken, then both the learning outcome and the programme outcome will be enhanced. This way, the Programme Educational Objectives (PEO) as enunciated by COREN (2017:2) will be achieved. Thus, the young engineer will be better able to contribute meaningfully to sustainable engineering and technology in an emerging economy such as Nigeria's. This young engineer will also be living up to the expectations of people like Obiazi (2015) who states that engineers are agents of change, creativity, innovation and invention. 
However, knowing what to do is one thing and doing exactly that is another thing. There must be the will to do the right thing, both on the part of the lecturers, the proprietors of the different institutions and the regulatory authorities. The time to act is now.

The second research question was aimed at finding out the extent of exposure of engineering students to some OBE assessment strategies which their lectures are already aware of. These assessment modes include workshop practice, laboratory practicals, students' industrial work experience scheme, term papers, seminars etc. Again, the items used for this investigation yielded an average mean of 2.85 signifying that the students are actually assessed using these modes. This is a step in the right direction as these modalities can provide the needed feedback to both the lecturers and the students. This way, the student gets to know his strengths and weaknesses and the necessary direction and guidance may then be provided. Thus, the students are equipped to be resourceful, creative, knowledgeable and able to perform the functions enunciated by NUC (2018:3). They will also be better equipped to be "suitable candidates for self-employment, and employment in public service or in the organized private sector" (COREN 2017:2). This way, the young engineer will be stronger and the transformation gained can pummel him/her to greater heights to make meaningful contribution to sustainable engineering.

The third research question sought to investigate adequacy of facilities that aid outcome based education assessment. An average mean of 2.18 was recorded. This implies that the facilities are not adequate, where they are available. All the specific items listed for the investigation attracted means less than 2.50, the criterion mean. The facilities include classrooms space, vehicles for field trips, workshop equipment, workshop space, laboratory equipment and space, internet/e-learning facilities, auto-cad studios, simulation studios and electricity supply. The researchers note that engineering is a programme that requires lavish availability of equipment and other facilities. It is learnt by apprenticeship. As such, the student will experiment with equipment. A situation where students are asked to provide their own tools or replace any item they damage in the process of learning cannot ginger a robust participation. Also, the attempt to preserve available equipment for accreditation purposes only, without allowing students train with them is worrisome. Epileptic power supply is anti "hands on tools". The result is that students are mainly assessed theoretically or they present items which the lecturer does not know where and how they were produced. This is disheartening. Some of the students engage technicians outside the university environment to produce some of these items at a fee. The items are then presented for assessment. This is counterproductive and cannot lead to the setting painted by the president of COREN, Abdukarim, Ali in his 2018 address to committee of Deans of Engineering and Technology of Nigerian Universities (CODET) when he boasted that "very soon Nigerian engineering profession will be among the 'Elite Group' ". Seminars and other interactive sessions need to be done in a conducive space and environment to bring out the best in the student. 'The world has become a global village' but this will be meaningless if the engineering student is not able to freely explore his horizon and deploy his superior intelligence for the benefit of mankind. Whatever gains that may appear to be recorded are merely transient and cannot lead to sustainable engineering and technology in Nigeria's emerging economy.

The assessment of students' use of equipment and other tools was the subject of research question four. This was geared towards assessing students "hands on tools". The question attracted a mean of 2.24 which is below the decision mean of 2.50 . This means that lecturers and other assessors do not assess students on the use of available equipment. The practitioner 
must be conversant with his tools. The engineer is not an exception. In fact, the engineer is the professional that needs this most. It is worrisome that all the items of this research question attracted very low individual means. These items include identification of machine parts, explanation of the functions of the machine parts, principles and guideline for operation, maintenance of equipment/tool and demonstration of hands on tools for production. Where a student is not conversant with the tool he/she is to work with, he/she cannot be expected to make effective use of the equipment. He/she will try every tactic to avoid the actual use of the equipment. The student develops a phobia and the result is that projects are contracted out. The system begins to deceive itself and the ideals of OBE are negated. As observed by participants at the $26^{\text {th }}$ COREN engineering assembly, the "outcome based curriculum is expected to give the students early start in the engineering life and also improve their mobility across the globe" (COREN, 2018). For there to be sustainability in engineering, therefore, there must be concerted efforts to insist on and implement hands on tools.

\section{Conclusion}

Outcome based education system for the Nigerian Engineering education system is desirable and accepted. Engineering lecturers are already practicing those strategies that could lead to a quality and transformative assessment under the system. However, the facilities that will aid the assessment are largely not available. The result is that both the students and their lecturers do not practice enough with the needed facilities. Irregular supply of electricity aggravates the situation as some lecturers do not even bother to enter the laboratories. Aggressive provision of needed facilities must be pursued for quality and transformation to be achieved.

\section{Recommendations}

1. Proprietors of universities and other institutions of higher learning should endeavour to provide needed facilities to aid the outcome based education system in engineering.

2. Access to the internet and other e-learning facilities within the respective campuses should be enhanced as this will encourage creativity and access to information among students and their lecturers.

3. Auto-cad and simulation studios should be robustly available to enhance meaningful experimentation with its attendant breakthroughs.

4. Regular supply of electricity to engineering laboratories and workshops should be made a priority by management of institutions, for $\mathrm{OBE}$ in engineering and students assessment there-in to be achieved.

5. Continuous assessment of students' outputs should be enhanced. This should include students' participation in group projects and ability to organize and formulate ideas.

6. Outcome based education system in engineering and its assessment demand dedicated effort from the engineering lecturers and as such, the need to be adequately remunerated to achieve the ideals of the programme. 


\section{REFERENCES}

Ali, K.A. (2018). "Goodwill Message from the President of COREN" An address presented at the $21^{\text {st }}$ Biannual Genera Meeting of Committee of Deans of Engineering and Technology of Nigerian Universities (CODET).

COREN (2017). Outcome Based Engineering Education: Benchmark on Minimum Academic Standards (BMAS) and Accreditation Scoring Criteria for Undergraduate Engineering Programmes in Nigerian Universities.

COREN (2018). "Communique Issued at the End of the $26^{\text {th }}$ Engineering Assembly held at the international conference centres, Abuja". Proceedings of the $27^{\text {th }}$ Engineering Assembly, Abuja, Nigeria.

Google.com (2017). "Engineering Transformation".

Nkwocha, P.C. (2014). Basics of Educational Measurement and Evaluation. Owerri. Liu House of Excellence Ventures.

NUC (2018). Benchmark Minimum Academic Standards for Undergraduate Programmes in Nigeria Universities. Engineering and Technology.

Obiazi, A. (2015). "Industrialization as a catalytic Engine of growth to transform Nigeria into a modular Economy". Paper presented at the $24^{\text {th }}$ COREN engineering assembly. Abuja, Nigeria.

Onyeka, J.N. \& Onuekwusi, C.N. (2019). Towards National Security: The need for Versatility and Creativity in Education Research Designs (NAJES, Alvan) 3(1), 39-47.

Onyeka, J.N. \& Dara, A.O. (2016). Quality Assessment and Teacher Preparation: Implications for the Post Graduate Diploma in Education Programme of the National Teachers Institute, ASSEREN 1(1), 213-220.

Onyeka, J.N. \& Onuekwusi, C.N. (2017). Quality Assessment of Entrepreneurship Skills in Tertiary Institutions in Imo State: A Necessary Step in the Attainment of sustainable development goals. Journal of Curriculum and Instruction (WCC1) 2 (3), 116-123.

Onyeka, J.N. (2012). "Qualitative Evaluation in Education: The bedrock for national integration" Eastern COEASSU Journal of Teacher Education (ECOJOTE) 5 (1). 112-119.

Onyeka, J.N., Onuekwusi, C.N., \& Dara, A.O. (2018). The role of Quality Assessment in improving Technological commercialization in Nigeria: The Case of Engineering Faculties in Universities in Imo State. Journal of Science, Technology, Mathematics and Education (JOSTMED). 14 (1), 156-164.

Unamba, E.C. Onuekwusi, C.N., \& Onyeka, J.N. (2017). Effects of two Assessment Methods on Achievement of Students in Trigonometry in Owerri, Municipal Council Area of Imo State. ASSEREN 2 (1),113-122. 